\title{
Donation interview before to brain death
}

\author{
A Fernandez Carmona 1*, M Sevilla Martínez', JM Perez Villares' ${ }^{1}$ R Lara Rosales ${ }^{1}$, EP Fuentes Garcia ${ }^{2}$ \\ From ESICM LIVES 2015 \\ Berlin, Germany. 3-7 October 2015
}

\section{Introduction}

The family interview to request donation is one of the key stages of obtaining organs for transplantation. The donation interview before to brain death (DIBBD) is done in two stages: in the emergency room or hospital ward, with prior notification of the existence of a severe neurological injury with a fatal short-term prognosis and which is dismissed surgery or ICU admission or when the family members of patients are informed of the seriousness of the process and requesting the withdrawal of life support measures.

\section{Objectives}

Analyze the results of DIBBD performed in a single tertiary level centre.

\section{Material and Methods}

Unicentric longitudinal descriptive study. Including all DIBBD performed since January 2011 until October 2014. All cases were registered in a focused database, including demographics data, place where the interview take place, time from admission to interview, time from interview to death and interview result and donation data (real and effective donors).

\section{Results}

During this period, 38 DIBBD were performed. The DIBBD during this period was $34 \%$ of donation interviews realized in our center.

Family approval to organ donation in case of brain death was $92,10 \%(35)$.

$60,5 \%$ of DIBBD were performed in a emergency room. The reasons for emergency admission were: hemorrhagic stroke in $74 \%$ of cases, ischemic stroke $13 \%$ and Traumatic Brain 3\%, others $10 \%$.

The mean age average of patients admitted to the ICU after DIBBD was 73,5 years.

${ }^{1}$ Virgen de las Nieves Hospital, Intensive Care Medicine, Granada, Spain Full list of author information is available at the end of the article
Within the group of patients admitted in ICU after DIBBD, the donation was contraindicated in 5 patients, also 5 patients died from cardiac arrest. All of the rest of the series developed encephalic death (25 patients) and $80 \%$ were effective donors (20 patients).

\section{Conclusions}

DIBBD results was very satisfactory, the results was positive in $92,10 \%$ of cases.

In our centre DIBBD implementation has increased potential donors detection as well as the final number of donations. Improving others professionals implication (emergency area, hospital ward...) in this process.

Most of the DIBBD was realized to families of 70-year-old major patients.

\section{Authors' details}

${ }^{1}$ Virgen de las Nieves Hospital, Intensive Care Medicine, Granada, Spain.

${ }^{2}$ Hospital Universitario San Cecilio, Intensive Care Medicine, Granada, Spain.

Published: 1 October 2015

doi:10.1186/2197-425X-3-S1-A903

Cite this article as: Fernandez Carmona et al:: Donation interview before to brain death. Intensive Care Medicine Experimental 2015 3(Suppl 1):A903.

Submit your manuscript to a SpringerOpen ${ }^{\circ}$ journal and benefit from:

- Convenient online submission

- Rigorous peer review

- Immediate publication on acceptance

- Open access: articles freely available online

- High visibility within the field

- Retaining the copyright to your article

Submit your next manuscript at $>$ springeropen.com
SpringerOpen $^{\odot}$

(c) 2015 Fernandez Carmona et al.; This is an Open Access article distributed under the terms of the Creative Commons Attribution License (http://creativecommons.org/licenses/by/4.0), which permits unrestricted use, distribution, and reproduction in any medium, provided the original work is properly cited. 